\title{
Árangur kransæðahjáveituaðgerða og ósæðarlokuskipta hjá öldruðum
}

\author{
Martin Ingi Sigurðsson ${ }^{1,2,3}$ læknir, Sólveig Helgadóttir ${ }^{1}$ læknir, Inga Lára Ingvarsdóttir ${ }^{1}$ læknir, Sindri Aron Viktorsson ${ }^{3}$ læknanemi, \\ Kári Hreinsson ${ }^{2}$ læknir, Pórarinn Arnórsson ${ }^{1}$ læknir, Tómas Guðbjartsson ${ }^{1,3}$ læknir
}

\section{ÁGRIP}

Tilgangur: Að kanna árangur opinna hjartaskurðaðgerða hjá sífellt stækkandi hópi sjúklinga eldri en 75 ára á Íslandi.

Efniviður og aðferðir: Afturskyggn rannsókn á sjúklingum sem gengust undir kransæðahjáveitu- og/eða ósæðarlokuskipti vegna ósæðarlokuprengsla á Landspítala frá 2002 til 2006. Kannaðir voru fylgikvillar, skurðdauði (<30 daga) og lifun sjúklinga 75 ára og eldri ( $n=221,25 \%)$ og peir bornir saman við yngri sjúklinga $(n=655,75 \%)$. Einnig var lifun eldri sjúklinga borin saman við lifun viðmiðunarhóps af sama kyni og á sama aldri. Niðurstöður: Eldri sjúklingar höfðu hærri tíðni gáttatifs (57\% sbr. 37\%, $\mathrm{p}<0,001)$, heilablóðfalls ( $5 \%$ sbr. $1 \%, p=0,009)$, og skurðdauða ( $9 \%$ sbr. $2 \%, p<0,001)$ eftir kransæðahjáveituaðgerð, miðað við yngri sjúklinga. Legutími á gjörgæslu var sambærilegur en heildarlegutími degi lengri hjá eldri hópnum. Eftir ósæðarlokuskipti höfðu eldri sjúklingar hærri tíðni gáttatifs $(90 \%$ sbr. $71 \%, p=0,006)$, bráđs andnauðarheilkennis $(19 \%$ sbr. $7 \%, p=0,04)$, hjartadreps $(21 \%$ sbr. $8 \%, p=0,05)$ og skurðdauða $(11 \%$ sbr. $2 \%, p=0,04)$, miðað við yngri hópinn. Legutími á gjörgæslu var degi lengri og heildarlegutími tæpum fjórum dögum lengri. Alls voru $75 \%$ eldri sjúklinga á lífi 5 árum eftir kransæðahjáveituađgerð samanborið við $74 \%$ viðmiðunarhóps $(p=0,87)$. Sambærilegar tölur eftir ósæðarlokuskipti voru $65 \%$ fyrir eldri sjúklinga, samanborið við $74 \%$ viðmiðunarhóps $(p=0,06)$. Umræða: Tíðni snemmkominna fylgikvilla, legutími og skurðdauði reyndist hærri hjá sjúklingum eldri en 75 ára samanborið við yngri sjúklinga. Lifun eldri hópsins bendir til ágæts langtímaárangurs opinna hjartaskurðaðgerða hjá pessum hópi sjúkinga.
${ }^{1} H$ jarta- og lungnaskurðdeild ${ }^{2}$ svæfinga- og gjörgæsludeild, Landspítala, ${ }^{3} æ k$ nadeild Háskóla Îslands.

Fyrirspurnir

Tómas Guð̋bjartsson

tomasgud@landspitali.is

Barst: 21. maí 2011, sampykkt til birtingar: 21. september 2011.

Engin hagsmunatengsl gefin upp.

\section{Inngangur}

Hátt í 6000 opnar hjartaskurðaðgerðir hafa verið framkvæmdar á Íslandi frá árinu 1986. Einkum er um að ræða kransæðahjáveituaðgerðir en einnig ósæðarlokuskipti vegna ósæðarlokuprengsla. ${ }^{1}$ Líkt og í nágrannalöndum okkar er stór hluti pessara sjúklinga um og yfir sjötugt. ${ }^{1-3}$ Ljóst er að aldurssamsetning pjóðarinnar er að breytast. Pannig hefur meðalaldur Íslendinga hækkað um tæplega 5 ár frá árinu 1980 til ársins 2010. Á sama tíma hefur hlutfall Íslendinga eldri en 75 ára aukist úr 4,1\% 1 5,8\%. ${ }^{4}$ Pví má gera ráð fyrir að eldri sjúklingum sem kunna að hafa hag af opnum hjartaskurðaðgerðum fjölgi á komandi árum.

Fjöldi erlendra rannsókna hefur staðfest ávinning opinna hjartaskurðaðgerða hjá völdum hópi eldra fólks. ${ }^{5-9}$ Pannig virðist ávinningur kransæðahjáveituaðgerðar umfram lyfjameðferð og kransæðavíkkun einnig vera til staðar hjá sjúklingum sem komnir eru yfir 75 ára aldur. ${ }^{8}$ Erlendar rannsóknir hafa að auki sýnt að lifun sjúklingahóps eftir ósæðarlokuskipti var sambærileg ${ }^{5,6}$ eða jafnvel betri ${ }^{7}$ en lifun viðmiðunarhóps af sama aldri og kyni. Aðgerðin virðist pví hafa lengt líf sjúklinganna. Ekki er síður mikilvægt að leggja mat á lífsgæði eldri sjúklinga eftir pessar aðgerðir. Pannig mátu sjúklingar í tveimur rannsóknum, bæði eftir sjötugt ${ }^{9}$ og eftir áttrætt, ${ }^{7}$ líkamlega heilsu sína betri en viðmiðunarhópur af sama aldri og kyni. Pá hefur verið sýnt fram á að kostnaður vegna kransæðahjáveituaðgerðar hjá sjúklingum eldri en 75 ára skilar sér til baka innan árs vegna færri kransæðapræðinga. ${ }^{10}$ Sambærileg greining á ávinningi ósæðarlokuskipta bendir til pess að fjárhagslegur ávinningur sé af lokuskiptum hjá sjúklingum eldri en 75 ára. ${ }^{11}$
Opnar hjartaskurðaðgerðir á eldri sjúklingum eru flóknari en hjá peim sem yngri eru og hætta á fylgikvillum og andláti umtalsvert hærri. Til dæmis reyndist skurðdauði á bilinu 7-30\% í hópi 80 ára og eldri ${ }^{7,12}$ og $18 \%$ hjá sjúklingum eldri en 90 ára. ${ }^{13}$ Fylgikvillar eru jafnframt tíðir, sérstaklega gáttatif sem greindist hjá næstum priðjungi sjúklinga yfir sjötugt. ${ }^{6,7}$

Af ofangreindu er ljóst að mikilvægt er að pekkja afdrif eldri sjúklinga eftir opnar hjartaskurðaðgerðir, bæði til lengri og skemmri tíma. Slíkar upplýsingar hafa ekki legið fyrir hér á landi og var markmið rannsóknarinnar að bæta úr pví. Litið var sérstaklega á fylgikvilla, dánartíðni og langtímalifun eldri sjúklinga og hún borin saman við yngri sjúklinga sem gengust undir opnar hjartaskurðaðgerðir hér á landi.

\section{Efniviður og aðferðir}

Rannsóknin var afturskyggn og náði til 876 sjúklinga sem gengust undir kransæðahjáveituaðgerð og/eða ósæðarlokuskipti vegna ósæðarlokuprengsla á Landspítala frá 1. janúar 2002 til 31. desember 2006. Sjúklingar voru fundnir með hjálp tveggja mismunandi skráa; annars vegar aðgerðaskrá hjarta- og lungnaskurðdeildar Landspítala og hins vegar úr sjúklingabókhaldi Landspítala. Áður en gagnaöflun hófst fékkst leyfi frá Vísindasiðanefnd, Persónuvernd og frá framkvæmdastjóra lækninga á Landspítala.

Klínískum upplýsingum um sjúklinga var safnað úr sjúkraskrám og voru meðal annars skráðar upplýsingar um aldur við aðgerð, kyn, áhættupætti kransæðasjúkdóms og fyrri hjartasögu. Einnig var skráð 


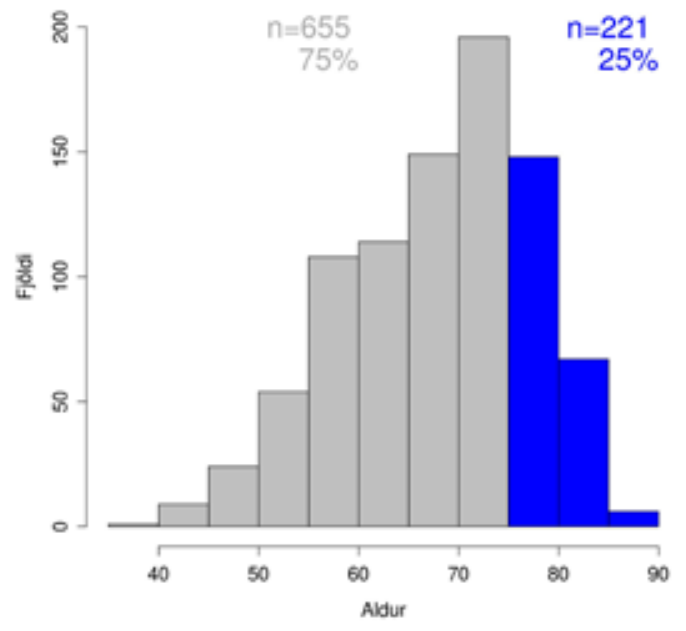

Mynd 1. Aldursdreifing sjúklinga sem gengust undir kransæðahjáveituaðgerð og/eða ósæðarlokuskipti á Íslandi á árunum 2002-2006. Sýnd er skipting sjúklinganna í yngri (gráar súlur) og eldri hóp (bláar súlur).

notkun hjarta-, blóðpynningar- og blóðflöguhemjandi lyfja og hvort sjúklingur hefði áður fengið nýrnabilun eða lungnasjúkdóma. Farið var yfir niðurstöður rannsókna sem gerðar voru fyrir aðgerð, meðal annars niðurstöður kransæðapræðingar og hjartaómskoðunar. Fyrir aðgerð var EuroSCORE (European System for Cardiac Operative Risk Evaluation) matskerfið notað til að gera staðlað áhættumat á líkum á andláti í kjölfar aðgerðar. ${ }^{14}$

Af sjúklingunum 876 gengust 720 undir kransæðahjáveituaðgerð (82\%), 86 undir ósæðarlokuskipti (10\%) og 70 sjúklingar gengust undir samhliða kransæðahjáveituaðgerð og ósæðarlokuskipti (8\%). Kransæðahjáveituaðgerðirnar voru ýmist gerðar með aðstoð hjarta- og lungnavélar $(n=536)$ eða á sláandi hjarta $(n=184)$. Af aðgerðartengdum breytum var skráð hvort um val- eða bráðaaðgerð var að ræða, aðgerðartími (húð til húðar), tími á hjarta- og lungnavél, tangartími (aortic cross clamp time), blæðing í brjóstholskera fyrstu 24 klukkustundir eftir aðgerð og magn blóðhlutagjafa í einingum.

Skráðir voru fylgikvillar allt til útskriftar af sjúkrahúsi eða fram að andláti. Fylgikvillum var skipt í minniháttar fylgikvilla (gáttatif/flökt, yfirborðssýking í skurðsári, lungnabólga, pvagfærasýking, aftöppun fleiðruvökva) og meiriháttar fylgikvilla (heilablóðfall, hjartadrep, djúp skurðsýking/hjartalokusýking, nýrnaskaði sem krafðist blóðskilunar eða fjöllíffærabilun). Skurðdauði var skilgreindur sem andlát innan 30 daga frá aðgerð. Gögn frá Hagstofu um dánardag og dánarorsök voru notuð til að reikna út lifun fram til 31. desember 2009. Úr sömu skrá fengust upplýsingar um hvort dánarorsök tengdist hjartasjúkdómi eða ekki. Miðgildi eftirfylgdar var 61 mánuðir (bil 0-97 mánuðir).

Sjúklingum var skipt í eldri og yngri hóp og var skiptingin miðuð við 75 ára aldur. Tíðni fylgikvilla og lifun var borin saman milli hópanna tveggja. Forspárpættir skurðdauða og langtímalifunar eldri hópsins voru svo kannaðir sérstaklega. Auk pess var langtímalifun hans borin saman við lifun viðmiðunarhóps Íslendinga af sama aldri og kyni sem var byggð á upplýsingum frá Hagstofu Íslands.

Gagnagrunnurinn var skráður í forritið Excel (Microsoft Corp, Redmond, WA). Lýsandi og greinandi tölfræði var unnin með $\mathrm{R}$, útgáfu 2.12.1. Við samanburð hópa var notast við t-próf eða Mann-Whitney próf fyrir samfelldar breytur og Fischer Exact eða Kí-kvaðrat próf fyrir hlutfallsbreytur. Langtímalifun var metin með aðferð Kaplan-Meier. Lifun samanburðarhóps var metin með notkun lifunartaflna Hagstofu og relsurv-pakkanum í $R$. Samanburður lifunarkúrfa var gerður með log-rank prófi. Sett var upp lógistískt áhættulíkan fyrir áhættupætti skurðdauða (logistic regression model). Fylgni breyta við langtímalifun var metin með áhættulíkani Cox (Cox proportional hazard model). Allar breytur sem notaðar voru í áhættulíkaninu stóðust kröfu um hlutfallsbil (proportionality). Tölfræðileg marktækni miðaðist við p-gildi <0,05.

Tafla I. Samanburður á áhættupáttum hjartasjúkdóma og niðurstöðum rannsókna hjá eldri ( $\geq 75$ ára) og yngri sjúklingum sem gengust undir kransæðahjáveituaðgerð eða ósæðarlokuskipti með/án kransæðahjáveituađgerðar á Íslandi 2002-2006. Gefinn er upp fjöldi sjúklinga og hlutföll i sviga (\%) en meðaltöl fyrir fjölda prengdra kransæða, útstreymisbrot og EuroSCORE.

\begin{tabular}{|c|c|c|c|c|c|c|c|c|c|}
\hline & \multicolumn{3}{|c|}{ Allir } & \multicolumn{3}{|c|}{ Kransæðahjáveituaððgerð eingöngu } & \multicolumn{3}{|c|}{ Ósæðarlokuskipti með/án kransæðahjáveituaðgerðar } \\
\hline & $\begin{array}{l}\text { Yngri } \\
\text { sjúklingar } \\
(n=655)\end{array}$ & $\begin{array}{c}\text { Eldri } \\
\text { sjúklingar } \\
(n=221)\end{array}$ & p-gildi & $\begin{array}{c}\text { Yngri } \\
\text { sjúklingar } \\
(n=571)\end{array}$ & $\begin{array}{c}\text { Eldri } \\
\text { sjúklingar } \\
(n=149)\end{array}$ & p-gildi & $\begin{array}{l}\text { Yngri sjúklingar } \\
\qquad(n=84)\end{array}$ & $\begin{array}{l}\text { Eldri sjúklingar } \\
\qquad(\mathrm{n}=72)\end{array}$ & p-gildi \\
\hline Karlar & $543(83)$ & $108(67)$ & 0,001 & $483(85)$ & $108(73)$ & 0,001 & $60(71)$ & $41(57)$ & 0,09 \\
\hline Sykursýki & $110(17)$ & $25(11)$ & 0,07 & $95(17)$ & $14(9)$ & 0,04 & $69(18)$ & $61(15)$ & 0,83 \\
\hline Háprýstingur & $405(62)$ & $146(66)$ & 0,29 & $346(61)$ & $97(65)$ & 0,36 & $59(70)$ & $49(66)$ & 0,90 \\
\hline Blóðfituröskun & $385(59)$ & $104(47)$ & 0,004 & $346(61)$ & $75(50)$ & 0,03 & $39(47)$ & $29(41)$ & 0,55 \\
\hline Reykingar & $179(27)$ & $23(11)$ & $<0,001$ & $161(28)$ & $13(9)$ & $<0,001$ & $18(21)$ & $10(14)$ & 0,31 \\
\hline Hjartabilun & $88(13)$ & $56(25)$ & $<0,001$ & $71(12)$ & $25(17)$ & 0,21 & $17(20)$ & $31(43)$ & 0,004 \\
\hline $\begin{array}{l}\text { Fjöldi prengdra } \\
\text { kransæða }\end{array}$ & $2,6 \pm 0,8$ & $2,4 \pm 1$ & 0,001 & $2,6 \pm 0,4$ & $2,9 \pm 0,3$ & 0,02 & $1,2 \pm 1,3$ & $1,3 \pm 1,2$ & 0,45 \\
\hline $\begin{array}{l}\text { Útstreymisbrot } \\
\text { hjarta (Ejection } \\
\text { fraction, EF) }\end{array}$ & $53 \pm 21$ & $52 \pm 29$ & 0,42 & $53 \pm 11$ & $53 \pm 10$ & 0,51 & $58 \pm 1$ & $59 \pm 1$ & 0,06 \\
\hline $\begin{array}{l}\text { Hámarks } \\
\text { prýstingsfall yfir } \\
\text { ósæðarloku (mmHg) }\end{array}$ & Á ekki við & Á ekki við & Á ekki við & Á ekki við & Á ekki við & Á ekki við & $70 \pm 21$ & $78 \pm 29$ & 0,05 \\
\hline EuroSCORE (st) & $4,4 \pm 3,0$ & $7,8 \pm 3,0$ & $<0,001$ & $4,3 \pm 3,1$ & $7,4 \pm 2,8$ & $<0,001$ & $5,4 \pm 2,0$ & $8,7 \pm 2,9$ & $<0,001$ \\
\hline
\end{tabular}


Tafla II. Samanburður á aðgerðartengdum páttum í hópi eldri ( $\geq 75$ ára) og yngri sjúklinga sem gengust undir kransæðahjáveituaðgerð eingöngu eða ósæðarlokuskipti međlán kransæðahjáveituađgerðar á Íslandi 2002-2006. Gefin eru upp međaltöl og bil nema fyrir aðgerðartegund par sem lýst er fjölda sjúklinga og hlutfalli (\%).

\begin{tabular}{|c|c|c|c|c|c|c|}
\hline & \multicolumn{3}{|c|}{ Eingöngu kransæðahjáveituaðgerð } & \multicolumn{3}{|c|}{ Ósæðarlokuskipti með/án kransæðahjáveituaðgerðar } \\
\hline & Yngri sjúklingar $(n=571)$ & Eldri sjúklingar ( $n=149)$ & p-gildi & Yngri sjúklingar $(n=84)$ & Eldri sjúklingar $(n=72)$ & p-gildi \\
\hline Aðgerð á sláandi hjarta & $164(29)$ & $43(29)$ & - & Á ekki við & Á ekki við & - \\
\hline $\begin{array}{l}\text { Aðgerð með hjarta- og } \\
\text { lungnavél }\end{array}$ & $407(71)$ & $106(71)$ & 0,95 & $84(100)$ & $72(100)$ & - \\
\hline $\begin{array}{l}\text { Eingöngu } \\
\text { ósæðarlokuskipti }\end{array}$ & Á ekki við & Á ekki við & - & $42(50)$ & $28(39)$ & - \\
\hline $\begin{array}{l}\text { Ósæðarlokuskipti og } \\
\text { kransæðahjáveituaðgerð }\end{array}$ & Á ekki við & Á ekki við & - & $42(50)$ & $44(61)$ & 0,55 \\
\hline Aðgerðartími, mínútur & $204(85-555)$ & $206(110-370)$ & 0,81 & $277(140-560)$ & $288(135-690)$ & 0,44 \\
\hline Tangartími, mínútur & $42(13-191)$ & $42(19-134)$ & 0,90 & $121(57-280)$ & $127(64-264)$ & 0,37 \\
\hline Blæðing eftir aðgerð, mL & $1021(100-31820)$ & $1097(100-4425)$ & 0,41 & $1229(185-4980)$ & $1106(0-4760)$ & 0,432 \\
\hline $\begin{array}{l}\text { Gjöf rauðkornapykknis } \\
\text { eftir aðgerð, einingar }\end{array}$ & $2(0-88)$ & $3(0-31)$ & 0,02 & $6(0-29)$ & $9(0-46)$ & 0,03 \\
\hline
\end{tabular}

\section{Niðurstöður}

Aldursdreifing sjúklinga er sýnd á mynd 1, en 221 sjúklingur reyndist $\geq 75$ ára (25\%) og 665 yngri (75\%). Hjá sjúklingum sem gengust undir ósæðarlokuskipti var hærra hlutfall eldri sjúklinga en við kransæðahjáveituaðgerð ( $46 \%$ sbr. $21 \%$, p<0,001).

Í töflu I er samanburður á áhættupáttum kransæðasjúkdóms og niðurstöðum rannsókna í báðum hópum. Á meðal eldri sjúklinga sem gengust undir kransæðahjáveituaðgerð reyndist hlutfall karla, reykinga, sykursýki og blóðfituröskunar lægra. Fjöldi prengdra kransæða var hins vegar marktækt hærri í eldri hópnum. Í ósæðarlokuhópnum var marktækt hærra hlutfall eldri sjúklinga með langvinna hjartabilun fyrir aðgerð, hærra prýstingsfall yfir ósæðarloku og hærra EuroSCORE.
Aðgerðartengdir pættir eru sýndir í töflu II. Hlutfall kransæðahjáveituaðgerða á sláandi hjarta var sambærilegt milli eldri og yngri sjúklinga og sömuleiðis hlutfall sjúklinga sem gengust undir kransæðahjáveituaðgerð samhliða ósæðarlokuskiptum. Blæðing var sambærileg milli hópa en eldri sjúklingum voru gefnar marktækt fleiri einingar af rauðkornapykkni.

Í töflu III sjást fylgikvillar skurðaðgerðar eftir hópum. Meðal sjúklinga sem gengust undir kransæðahjáveituaðgerð var tíðni gáttatifs marktækt hærri í eldri hópnum (57\% sbr. 37\%, p<0,001) og gilti hið sama eftir ósæðarlokuskipti (90\% sbr. 71\%, p=0,006).

Hjá kransæðahjáveituhópnum var samanlögð tíðni allra meiriháttar fylgikvilla samanlagt marktækt hærri í eldri hópi en peim yngri, par á meðal tíðni heilablóðfalls (5\% sbr. 1\%, p=0,009). Eldri

Tafla III. Samanburðurá tíðni minniháttar fylgikvilla, meiriháttar fylgikvilla og skurðdauða milli eldri ( $\geq 75$ ára) og yngri sjúklinga sem gengust undir kransæðahjáveituaðgerð eingöngu eða ósæðarlokuskipti með/án kransæðahjáveituaðgerðar á Íslandi 2002-2006. Gefinn er upp fjöldi sjúklinga og \% í sviga.

\begin{tabular}{|c|c|c|c|c|c|c|c|c|c|}
\hline & \multicolumn{3}{|c|}{ Allir } & \multicolumn{3}{|c|}{ Eingöngu kransæðahjáveituaðgerð } & \multicolumn{3}{|c|}{$\begin{array}{l}\text { Ósæðarlokuskipti með/án } \\
\text { kransæðahjáveituaðgerðar }\end{array}$} \\
\hline & $\begin{array}{l}\text { Yngri sjúklingar } \\
\qquad(n=665)\end{array}$ & $\begin{array}{l}\text { Eldri sjúklingar } \\
\qquad(n=221)\end{array}$ & p-gildi & $\begin{array}{l}\text { Yngri sjúklingar } \\
\qquad(n=571)\end{array}$ & $\begin{array}{l}\text { Eldri sjúklingar } \\
\qquad(n=149)\end{array}$ & p-gildi & $\begin{array}{l}\text { Yngri sjúklingar } \\
\qquad(n=84)\end{array}$ & $\begin{array}{l}\text { Eldri sjúklingar } \\
\qquad(n=72)\end{array}$ & p-gildi \\
\hline Gáttatif & $269(41)$ & $150(68)$ & $<0,001$ & $209(37)$ & $85(57)$ & $<0,001$ & $60(71)$ & $65(90)$ & 0,006 \\
\hline Aftöppun fleiðruvökva & $80(12)$ & $35(16)$ & 0,21 & $70(12)$ & $24(16)$ & 0,27 & $10(12)$ & $11(15)$ & 0,70 \\
\hline Grunn skurðsýking & $58(9)$ & $13(9)$ & 0,96 & $52(9)$ & $13(9)$ & 0,99 & $6(8)$ & $7(10)$ & 0,77 \\
\hline Lungnabólga & $36(6)$ & $31(14)$ & $<0,001$ & $31(5)$ & $14(9)$ & 0,11 & $5(6)$ & $17(24)$ & 0,03 \\
\hline Pvagfærasýking & $23(4)$ & $33(15)$ & $<0,001$ & $12(2)$ & $15(10)$ & $<0,001$ & $11(13)$ & $18(25)$ & 0,089 \\
\hline Minniháttar fylgikvilli & 347 (53) & $173(78)$ & $<0,001$ & $284(50)$ & $107(72)$ & $<0,001$ & $63(75)$ & $66(92)$ & 0,01 \\
\hline Hjartadrep & $79(12)$ & $38(17)$ & 0,07 & $72(13)$ & $23(15)$ & 0,44 & $7(8)$ & $15(21)$ & 0,05 \\
\hline Heilablóðfall & $11(2)$ & $11(5)$ & 0,01 & $8(1)$ & $8(5)$ & 0,009 & $3(4)$ & $3(4)$ & 0,82 \\
\hline $\begin{array}{l}\text { Nýrnaskaði } \\
\text { sem parfnaðist } \\
\text { blóðskilunar }\end{array}$ & $9(1)$ & $3(1)$ & 0,99 & $9(2)$ & $3(2)$ & 0,99 & $0(0)$ & $0(0)$ & 1,00 \\
\hline $\begin{array}{l}\text { Djúp skurðsýking / } \\
\text { hjartapelsbólga }\end{array}$ & $5(1)$ & $1(1)$ & 0,99 & $5(1)$ & $1(1)$ & 0,79 & $0(0)$ & $0(0)$ & 1,00 \\
\hline Bringubeinslos & $14(2)$ & $10(5)$ & 0,10 & $12(2)$ & $7(5)$ & 0,14 & $2(2)$ & $3(4)$ & 0,86 \\
\hline $\begin{array}{l}\text { Fjöllíffærabilun / } \\
\text { andnauðarheilkenni }\end{array}$ & $21(3)$ & $22(10)$ & $<0,001$ & $15(3)$ & $8(5)$ & 0,15 & $6(7)$ & $14(19)$ & 0,04 \\
\hline Meiriháttar fylgikvilli & $112(17)$ & $69(32)$ & 0,01 & $99(17)$ & $42(28)$ & 0,004 & $13(16)$ & 27 (38) & 0,03 \\
\hline Skurðdauði & $12(2)$ & $21(10)$ & $<0,001$ & $10(2)$ & $13(9)$ & $<0,001$ & $2(2)$ & $8(11)$ & 0,003 \\
\hline
\end{tabular}



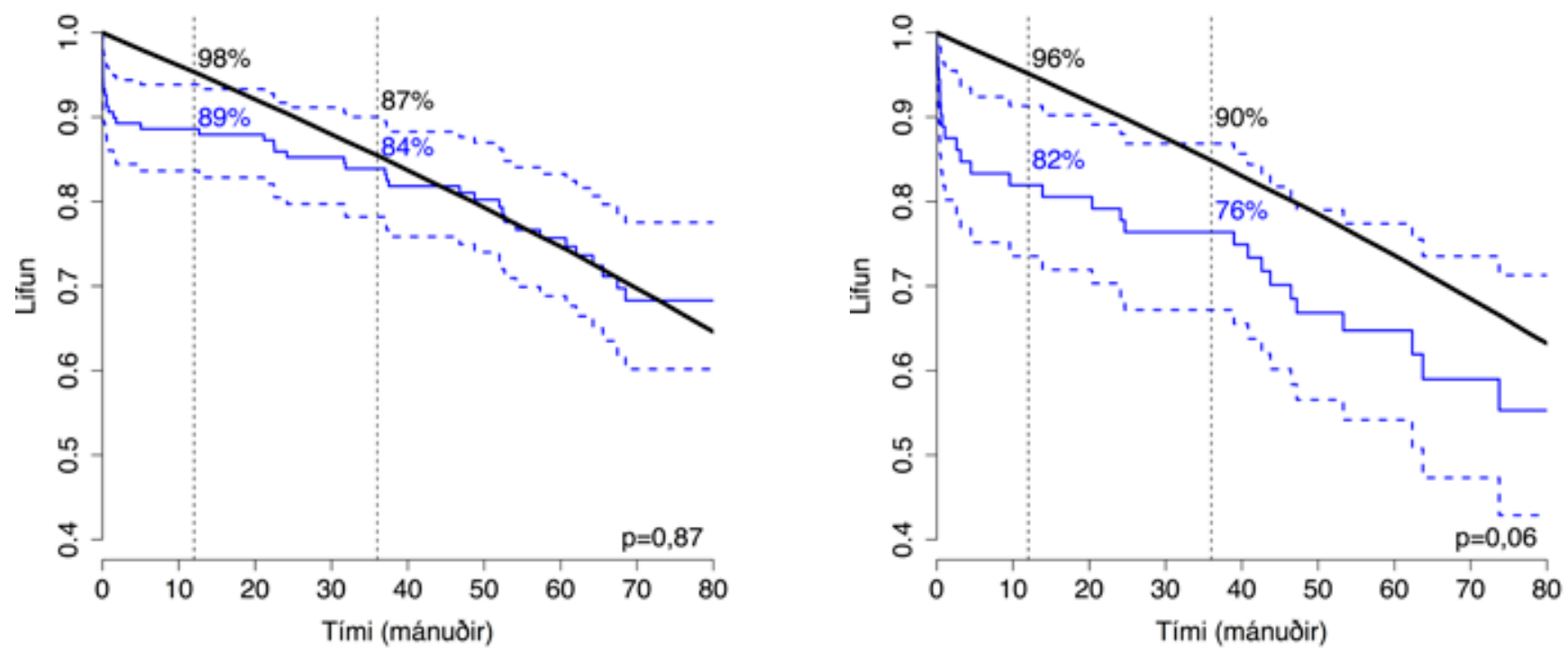

Mynd 2. Kaplan-Meier graf sem sýnir lifun sjúklinga 75 ára og eldri sem gengust undir kransæðahjáveituaðgerð eingöngu (mynd 2a) eða ósæðarlokuskipti með eða án kransæðahjáveitu (mynd 2b) á Íslandi frá 2002 til 2006 (blá lína, 95\% öryggisbil sýnd með bláum brotalínum), samanborið við viðmiðunarhóp Íslendinga af sama aldri og kyni (svört lína). Prósentutölur sýna lifun 12 og 36 mánuðum frá aðgerð. Lifun sjúklingahópsins var ekki marktækt frábrugðin lifun viðmiðunarhóps, hvorki eftir kransæðahjáveituaðgerð né ósæðarlokuskipti með eða án kransæðahjáveituaðgerðar.

sjúklingar í ósæðarlokuhópi voru hins vegar marktækt líklegri til að fá hjartadrep ( $21 \%$ sbr. $8 \%, p=0,05)$ eða fjöllíffærabilun $(19 \%$ sbr. $7 \%, \mathrm{p}=0,03)$. Auk pess var samanlögð tíðni allra meiriháttar fylgikvilla hærri.

Skurðdauði reyndist marktækt hærri í hópi eldri sjúklinga, bæði eftir kransæðahjáveitu (9\% sbr. 2\%, p<0,001) og ósæðarlokuskipti $(11 \%$ sbr. $2 \%, p=0,003)$ (tafla III). Ekki var tölfræðilega marktækur munur á skurðdauða milli sjúklinga 75-79 ára og sjúklinga 80 ára og eldri, hvorki eftir kransæðahjáveitu (6\% sbr. 16\%, p=0,06) né ósæðarlokuskipti (7\% sbr. 18\%, p=0,29). Fjölbreytugreining á áhættupáttum skurðdauða hjá sjúklingum 75 ára eða eldri sýndi að hærri aldur (OR 1,24, 95\% CI: 1,02-1,52, p=0,03) og hærra EuroSCORE (OR 1,26, 95\% CI: 1,02-1,56, p=0,03) voru sjálfstæðir forspárpættir skurðdauða. Hins vegar reyndust ósæðarlokuskipti ekki sjálfstæður forspárpáttur (OR 1,16, 95\% CI: 0,98-1,37, p=0,08).

Heildarlegutími var sólarhring lengri hjá eldri kransæðahjáveitusjúklingum (12 dagar sbr. 11 dagar að miðgildi, $\mathrm{p}<0,001$ ), en miðgildi legutíma á gjörgæslu var hið sama $(p=0,10)$. Legutími á gjörgæslu var sólarhring lengri hjá eldri hópnum eftir ósæðarlokuskipti með/án kransæðahjáveituaðgerðar (2 sbr. 1 dagar að miðgildi, $\mathrm{p}<0,001)$, og var heildarlegutími einnig lengri (15 sbr. $11,5$ dagar að miðgildi, $\mathrm{p}<0,001)$.

Eins árs og fimm ára lifun mældist $97 \%$ og $91 \%$ fyrir yngri sjúklingahópinn, samanborið við $86 \%$ og $71 \%$ hjá peim eldri $(\mathrm{p}<0,001$, log-rank próf). Sjúkdómasértæk lifun (disease specific survival) á sömu tímapunktum var $97 \%$ og 95\% fyrir yngri hópinn samanborið við $89 \%$ og $84 \%$ fyrir pann eldri ( $\mathrm{p}<0,001$, log-rank próf).

Á mynd 2 sést samanburður á heildarlifun sjúklinga 75 ára og eldri og samanburðarhóps Íslendinga af sama aldri og kyni, bæði fyrir kransæðahjáveituaðgerðir (mynd 2a) og ósæðarlokuskipti með/án kransæðahjáveituaðgerðar (mynd 2b). Tólf mánuð- um eftir kransæðahjáveituaðgerð skaraðist lifunarkúrfa viðmiðunarhópsins við 95\% vikmörk lifunarkúrfu sjúklingahópsins og ekki reyndist marktækur munur á lifun pessara hópa $(\mathrm{p}=0,87$, log-rank próf). Eftir ósæðarlokuskipti sköruðust pessar línur eftir rúma 30 mánuði. Prátt fyrir að lifun hópanna virtist framan af frábrugðin var munurinn ekki marktækur ( $\mathrm{p}=0,06$, log-rank próf). Cox-áhættulíkan hjá sjúklingum 75 ára og eldri sýndi aukna áhættu á skurðdauða með hækkandi aldri (HR 1,17, 95\% CI: 1,06$1,29, \mathrm{p}=0,002)$, en hærra útstreymisbrot vinstra slegils virtist verndandi páttur (HR 0,97, 95\% CI: 0,94-1,00, $\mathrm{p}=0,03$ ). Aðrar breytur í líkaninu (EuroSCORE, bráðaaðgerð, kyn) reyndust ekki sjálfstæðir áhættupættir skurðdauða.

\section{Umræða}

Rannsókn okkar sýnir að fjórðungur sjúklinga sem gekkst undir tvær algengustu opnu hjartaskurðaðgerðirnar á Íslandi er kominn yfir 75 ára aldur, og fyrir ósæðarlokuskipti er hlutfallið 46\%. Petta er nánast sama hlutfall og í sænska Swedeheart-grunninum sem nær til allra hjartaskurðdeilda í Svípjóð. ${ }^{15}$

Par sem aldursdreifing og tíðni fylgikvilla reyndist mismunandi fyrir kransæðahjáveituaðgerðir og ósæðarlokuskipti, ákváðum við að greina frá árangri aðgerðanna í tveimur hlutum. Í báðum hópum reyndust eldri sjúklingar síður líklegir en peir yngri til að reykja, hafa sykursýki eða blóðfituröskun (tafla I). Skýringin gæti verið sú að sjúklingar með óheppilega samsetningu áhættupátta hafi síður verið teknir til aðgerðar eða hafi jafnvel komið yngri inn í aðgerð. Hvort tveggja getur valdið bjögun í vali sjúklinga. Kransæðasjúkdómur var hins vegar útbreiddari í hópi eldri kransæðahjáveitusjúklinga og prýstingsfall hærra yfir ósæðarloku í eldri ósæðarlokuhópi. Eldri sjúklingar virðast pví hafa alvarlegri 
hjartasjúkdóm en peir yngri, sem er mikilvægt að hafa í huga pegar verið er að meta gagnsemi opinna hjartaskurðaðgerða í pessum hópi sjúklinga.

Ekki sást munur á aðgerðatengdum páttum fyrir eldri og yngri sjúklinga (tafla II). Eftir aðgerðina fengu eldri sjúklingarnir pó marktækt fleiri einingar rauðkornapykknis, enda pótt blæðing í báðum hópum hefði verið sambærileg. Hugsanlegt er að eldri sjúklingar hafi síður verið taldir pola blóðtap í kjölfar aðgerðar og peim pví frekar gefið blóð.

Legutími eldri sjúklinga eftir kransæðahjáveituaðgerð var 12 dagar (miðgildi), sem er heilum degi lengra en hjá yngri sjúklingum. Gjörgæslulega var hins vegar sambærileg í báðum hópum, eða einn dagur að miðgildi. Til samanburðar var legutími í rannsókn Krane og félaga 10 dagar, par af fjórir á gjörgæslu, en um var að ræða 403 sjúklinga eldri en 80 ára sem gengist höfðu undir kransæðahjáveituaðgerð. ${ }^{7}$ Í okkar rannsókn var legutími eftir ósæðarlokuskipti 15 dagar (miðgildi) sem er tæpum fjórum dögum lengra en hjá peim yngri. Einnig munaði degi á gjörgæslulegu sem var tveir dagar í eldri hópnum (miðgildi). Til samanburðar reyndist legutími sjúklinga eldri en 80 ára eftir ósæðarlokuskipti í tveimur erlendum rannsóknum á bilinu 10-14 dagar (miðgildi) en par af voru 4-5 dagar á gjörgæslu. ${ }^{6,7}$

Gáttatif reyndist algengasti fylgikvillinn, bæði meðal eldri og yngri sjúklinga, en í eldri hópnum var tíðnin 57\% í kjölfar kransæðahjáveituaðgerðar og 90\% eftir ósæðarlokuskipti. Reyndar er tíðni gáttatifs eftir hjartaskurðaðgerðir hér á landi með pví hæsta sem lýst hefur verið. ${ }^{16}$ Erlendis er hlutfall sjúklinga eldri en 80 ára sem fá gáttatif $25-30 \%$, hvort sem um kransæðahjáveituaðgerð eða ósæðarlokuskipti er að ræða. ${ }^{6,7}$ Pó hefur verið lýst allt að $60 \%$ tíðni gáttatifs eftir kransæðahjáveituaðgerð og ósæðarlokuskipti. ${ }^{17}$ Gáttatif eykur hættu á fylgikvillum á borð við heilablóðfall, ${ }^{17}$ auk pess sem sjúkrahúsdvöl lengist og par með kostnaður við aðgerðina. ${ }^{18}$ Tíðni heilablóðfalls var í hærra lagi og greindist hjá $4 \%$ sjúklinga 75 ára og eldri. Petta er tvöfalt hærra en í erlendum rannsóknum. ${ }^{7}$ Pó ber að hafa í huga að í okkar rannsókn voru teknir með sjúklingar með tímabundna blóðpurrð (TIA), sem hækkar tíðnina. Engu að síður er ljóst að hér á landi verður að leita leiða til að draga úr tíðni gáttatifs í kjölfar opinna hjartaskurðaðgerða, ekki síst í hópi eldri sjúklinga.

Dánartíðni innan 30 daga hjá sjúklingum 75 ára og eldri reyndist 9\% eftir kransæðahjáveituaðgerð eingöngu, en 11\% eftir ósæðarlokuskipti með/án kransæðahjáveituaðgerðar. Til samanburðar var dánartíðni í grein Krane og félaga á 1003 sjúklingum eldri en 80 ára eftir kransæðahjáveituaðgerð 7,4\%, en 8,9\% fyrir sjúklinga sem gengust undir ósæðarlokuskipti með/án kransæðahjáveituaðgerðar.7 Svipaðar niðurstöður sáust í uppgjöri Collart og félaga á 215 sjúklingum eldri en 80 ára sem gengust undir ósæðarlokuskipti, en par var skurðdauði 8,8\%. ${ }^{6}$ Fæð sjúklinga yfir áttræðu í okkar rannsókn torveldar pó samanburð við erlendar rannsóknir. Ekki reyndist marktækur munur á skurðdauða sjúklinga 75-79 ára og sjúklinga 80 ára og eldri, en fjöldi sjúklinga í hópnum 80 ára og eldri er svo lítill að ekki er unnt að álykta um tölfræðilega marktækni pó allnokkru muni á dánarhlutfalli hópanna.

prír af hverjum fjórum sjúklingum yfir 75 ára aldri voru á lífi 5 árum eftir kransæðahjáveituaðgerð. Lifun peirra reyndist sambærileg við lifun viðmiðunarhóps Íslendinga af sama kyni og aldri. Til samanburðar voru tæplega tveir priðju ósæðarlokuskiptasjúklinga á lífi 5 árum eftir aðgerð, sem er heldur lakari lifun en hjá viðmiðunarhópi. Munurinn í lifun náði pó ekki tölfræðilegri marktækni $(\mathrm{p}=0,06)$, enda sjúklingar tiltölulega fáir. Niðurstöður okkar eru í samræmi við erlendar rannsóknir og benda til pess að eldri sjúklingum geti farnast vel eftir aðgerð, jafnvel álíka vel og jafnöldrum peirra sem ekki hafa gengist undir hjartaskurðaðgerð. ${ }^{5-7,19}$ Pví virðist sem opnar hjartaskurðaðgerðir bæti umtalsvert lífshorfur eldri sjúklinga, að minnsta kosti peirra sem útskrifast án alvarlegra fylgikvilla.

Í stuttu máli sagt er tíðni fylgikvilla eftir opnar hjartaskurðaðgerðir há fyrir sjúklinga eldri en 75 ára, einkum tíðni gáttatifs. Legutími á deildum og gjörgæslu er einnig langur og dánartíðni frekar há, sem pó er í samræmi við erlendar rannsóknir. Langtímalifun pessa sjúklingahóps er hins vegar ágæt. Petta sést best á pví að einum til premur árum frá aðgerð er lifun sjúklinganna sambærileg við lifun viðmiðunarhóps. Niðurstöður okkar eru mikilvægt innlegg við mat á ávinningi og áhættu opinna hjartaskurðaðgerða hjá eldri sjúklingum. Petta á ekki síst við pegar opnar hjartaskurðaðgerðir eru bornar saman við nýrri meðferðir eins og ísetningu ósæðarloka með hjartapræðingartækni.

\section{Pakkir}

Pakkir fær Gunnhildur Jóhannsdóttir, skrifstofustjóri á skurðdeild Landspítala, fyrir aðstoð við leit að sjúkraskrám. Pessi rannsókn var styrkt af Vísindasjóði Landspítala og Styrktar- og verðlaunasjóði Bent Schevings Thorsteinssonar.

\section{Heimildir}

1. Smárason, NV, Sigurjónsson H, Hreinsson $K$, Arnórsson T, Gudbjartsson T. Enduraðgerðir vegna blæðinga eftir opnar hjartaskurðaðgerðir á Íslandi. Læknablaðið 2009; 95: 567-73.

2. Sigurjonsson $\mathrm{H}$, Helgadottir S, Oddsson S, Arnorsson T, Gudbjartsson T. Árangur kransæðahjáveituaðgerða á Íslandi. Læknablaðið 2010; Fylgirit 62: V-08.

3. Ingvarsdóttir I, Helgadóttir S, Danielsen R, Guðbjartsson T. Lokuskipti vegna ósæðarlokuprengsla á Íslandi 20022006. Læknablaðið 2010; Fylgirit 62: E-37.

4. Hagstofa Íslands. Yfirlit yfir mannfjölda 1841-2011. www. hagstofa.is - mars 2011.

5. Cane ME, Chen C, Bailey BM, Fernandez J, Laub GW, Anderson WA et al. CABG in octogenarians: early and late events and actuarial survival in comparison with a matched population. Ann Thorac Surg 1995; 60: 1033-7.
6. Collart F, Feier H, Kerbaul F, Mouly-Bandini A, Riberi A, Mesana TG, et al. Valvular surgery in octogenarians: operative risks factors, evaluation of Euroscore and long term results. Eur J Cardiothorac Surg 2005; 27: 276-80.

7. Krane M, Voss B, Hiebinger A, Deutsch MA, Wottke M, Hapfelmeier A, et al. Twenty years of cardiac surgery in patients aged 80 years and older: risks and benefits. Ann Thorac Surg 2011; 91: 506-13.

8. Pfisterer M. Long-term outcome in elderly patients with chronic angina managed invasively versus by optimized medical therapy: four-year follow-up of the randomized Trial of Invasive versus Medical therapy in Elderly patients (TIME). Circulation 2004; 110: 1213-8.

9. Tseng EE, Lee CA, Cameron DE, Stuart RS, Greene PS, Sussman MS, et al. Aortic valve replacement in the elderly. Risk factors and long-term results. Ann Surg 1997; 225: 793-802.
10. Claude J, Schindler C, Kuster GM, Schwenkglenks M, Szucs T, Buser P, et al. Cost-effectiveness of invasive versus medical management of elderly patients with chronic symptomatic coronary artery disease. Findings of the randomized trial of invasive versus medical therapy in elderly patients with chronic angina (TIME). Eur Heart J 2004; 25: 2195-203.

11. Wu Y, Jin R, Gao G, Grunkemeier GL, Starr, A. Costeffectiveness of aortic valve replacement in the elderly: an introductory study. J Thorac Cardiovasc Surg 2007; 133: 608-13.

12. Viana-Tejedor A, Domínguez FI, Moreno Yangüela $M$ Moreno R, López de Sá E, et al. [Cardiac surgery in octogenarian patients: evaluation of predictive factors of mortality, long-term outcome and quality of life]. Med Clin (Barc) 2008; 131: 412-5. 
13. Easo J, Hölzl PP, Horst M, Dikov V, Litmathe J, Dapunt O. Cardiac surgery in nonagenarians: Pushing the boundary one further decade. Arch Gerontol Geriatr 2010; 53: 229-32.

14. Roques F, Nashef SA, Michel P, Gauducheau E, de Vincentiis C, Baudet E, et al. Risk factors and outcome in European cardiac surgery: analysis of the EuroSCORE multinational database of 19030 patients. Eur J Cardiothorac Surg 1999; 15: 816-22

15. Jernberg $T$, Attebring MF, Hambraeus $K$, Ivert $T$, Jame $\mathrm{S}$, Jeppsson A, et al. The Swedish Web-system for enhancement and development of evidence-based care in heart disease evaluated according to recommended therapies (SWEDEHEART). Heart 2010; 96: 1617-21.
16. Helgadottir $\mathrm{S}$, Sigurionsson $\mathrm{H}$, Ingvarsdottir $\mathrm{I}$, Oddsson SJ, Sigurdsson MI, Arnar DO, et al. Gáttatif eftir opnar hjartaaðgerðir á Íslandi. Læknablaðið 2010; Fylgirit 62 : E-27.

17. Creswell LL, Schuessler RB, Rosenbloom M, Cox JL Hazards of postoperative atrial arrhythmias. Ann Thorac Surg 1993; 56: 539-49.

18. Hravnak M, Hoffman LA, Saul MI, Zullo TG, Whitman GR. Resource utilization related to atrial fibrillation after coronary artery bypass grafting. Am J Crit Care 2002; 11: 228-38.
19. Adkins MS, Amalfitano D, Harnum NA, Laub GW, McGrath LB. Efficacy of combined coronary revascularization and valve procedures in octogenarians. Chest 1995; 108: 927-31.

\section{ENGLISH SUMMARY}

\section{The outcomes of coronary artery bypass and aortic valve replacement in elderly patients}

Sigurdsson $\mathrm{MI}^{1,2,3}$, Helgadottir S 1 , Ingvarsdottir IL ${ }^{1}$, Viktorsson SA ${ }^{3}$, Hreinsson $\mathrm{K}^{2}$, Arnorsson Th1', Gudbjartsson $\mathrm{T}^{1,3}$

Objective: To study the outcome of open heart surgery in an increasing population of elderly patients in Iceland.

Material and methods: A retrospective study of patients $(n=876)$ that underwent coronary artery bypass (CABG) or aortic valve replacement (AVR) for aortic stenosis in Iceland 2002-2006. Complication rates, operative mortality and long-term survival were compared between patients older $(n=221,25 \%)$ and younger $(n=655,75 \%)$ than 75 years. Long-term survival of the older group was compared to an age and sex matched reference population.

Results: Older patients had a higher incidence of atrial fibrillation $(57 \%$ vs. $37 \%, p<0.001)$, stroke $(5 \%$ vs. $1 \%, p=0.009)$ and operative mortality $(9 \%$ vs. $2 \%, p<0.001)$ following CABG. Length of ICU stay was similar but total length of stay was one day longer in the older cohort. Following
AVR, older patients had a higher incidence of atrial fibrillation $(90 \%$ vs. $71 \%, p=0.006)$, ARDS $(19 \%$ vs. $7 \%, p=0.04)$, myocardial infarction $(21 \%$ vs. $8 \%, p=0.05)$ and operative mortality ( $11 \%$ vs. $2 \%, p=0.04)$. The ICU stay was a day longer and the total length of stay was about four days longer in the older cohort. A total of $75 \%$ of the older patients were alive five years after CABG, compared to $74 \%$ of the reference population $(p=0.87)$. Similar numbers for AVR were $65 \%$ for the patients compared to $74 \%$ in the reference population $(\mathrm{p}=0.06)$.

Conclusion: The rate of complications, operative mortality and length of hospital stay is higher in patients older than 75 years compared to younger patients. Survival of the older group of patients indicates good long-term results after open heart surgery for this patient cohort.

Keywords: coronary artery bypass, aortic valve replacement, survival, complications, older patients.

Correspondence: Tómas Guðbjartsson, tomasgud@landspitali.is

${ }^{1}$ Department of Cardiothoracic Surgery, ${ }^{2}$ Department of Intensive Care and Anaethesiology, Landspitali University Hospital, Reykjavik, Iceland, ${ }^{3}$ Faculty of Medicine, University of Iceland, Reykjavik, Iceland. 